\title{
Repeatability of respiratory data in the individual subject
}

\author{
LINDSAY DAVIDSON
}

\section{From the Department of Medicine, Queen Elizabeth Hospital, Birmingham ${ }^{1}$}

A knowledge of the repeatability of any respiratory measurement in the individual is a prerequisite when assessing the significance of the change in state produced by any experimental procedure. Such information is available in the literature only in scattered and incomplete detail.

The accompanying Table presents such data, and, as the high degree of repeatability in the individual is often not appreciated, a record of the published variation for normal groups is included for comparison.

All measurements are based on duplicate sampling compared with duplicate sampling 10 minutes later. Details of the methods are available together with a complete statistical analysis in the author's M.D. thesis (1962) of the University of Birmingham. The patients were undergoing thoracic, abdominal, and other major surgical procedures. Measurements were made pre-operatively and 24 hours post-operatively, and there was no difference between the statistical analysis

${ }^{1}$ Present address : Department of Medicine, University College of Rhodesia and Nyasaland, Harari Hospital, P.O. Box ST.14, Southerton, Rhodesia of differences pre-operatively and post-operatively.

It is hoped that the publication of these data will help investigators to define a steady state in their patients.

\section{REFERENCES}

Bartels, H., and Rodewald, G. (1952). Der arterielle Sauerstoffdruck, die alveolär-arterielle Sauerstoffdruckdifferenz und weitere atmungsphysiologische Daten gesunder Männer. Pflugers. Arch. ges. Physiol., 256, 113.

Greifenstein, F. E, King, R. M., Latch, S. S., and Conroe, J. H., jun, (1952). Pulmonary function studies in healthy men and women 50 years and older. J. appl. Physiol., 4, 641.

Handbook of Respiration (1958). National Academy of Sciences, National Research Council. Edited by D. S. Dittmer and R. M. Grebe. Saunders, Philadelphia.

Kory, R. C., Callahan, R., Boren, H. G., and Syner, J. C. (1961). The Veterans Administration-Army Co-operative Study of Pulmonary Function I. Clinical spirometry in normal men. Amer. J. Med., 30, 243.

Raine, J. M., and Bishop, J. M. (1963). A-a difference in $\mathrm{O}_{2}$ tension and physiological dead space in normal man. J. appl. Physiol., 18, 284.

Riley, R. L., Campbell, E. J. M., and Shepard, R. H.(1957). A bubble method for estimation of $\mathrm{PCO}_{2}$ and $\mathrm{Po}$, in whole blood. J. appl. Physiol., 11, 245.

Cournand, A., and Donald, K. W. (1951). Analysis of factors affecting partial pressures of oxygen and carbon dioxide in gas and blood of lungs : methods. Ibid., 4, 102.

Shock, N. W., and Yiengst, M. J. (1955). Age changes in basal respiratory measurements and metabolism in males. J. Geront., 10 , 31 .

T A B LE

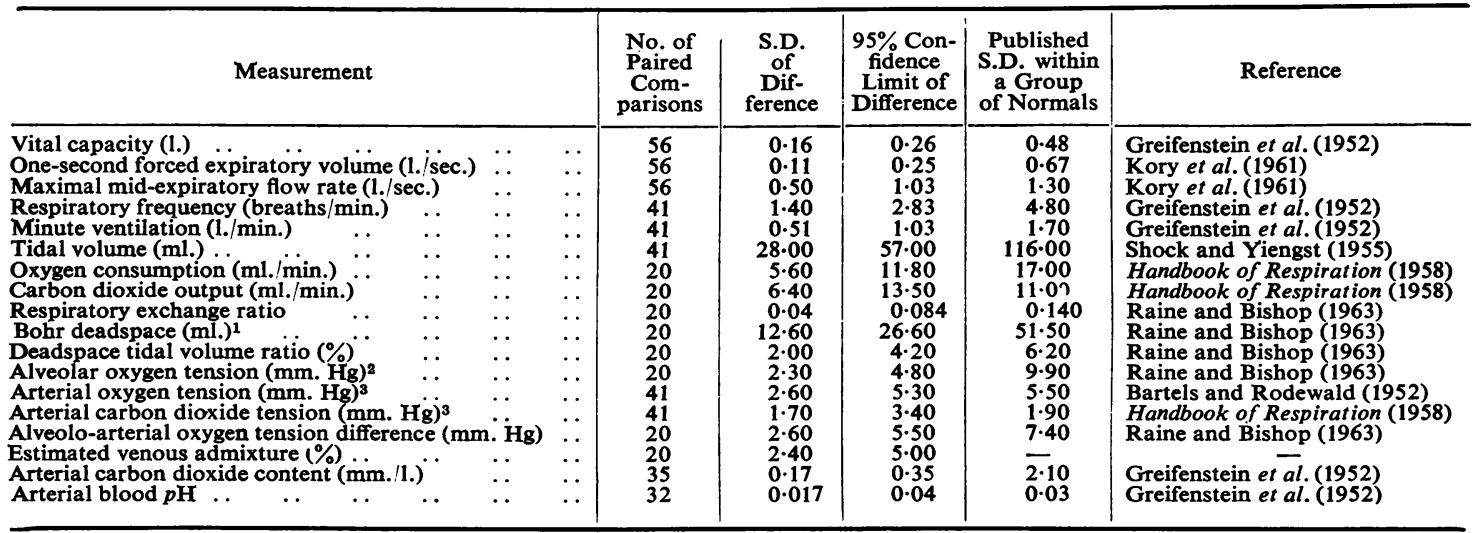

Notes: ${ }^{1}$ Assuming $\mathrm{PACO}_{2}=\mathrm{PaCO}_{2}$.

2 Calculated from alveolar air equation.

3 Microtonometry (Riley, Campbell, and Shepard, 1957).

4 Charts of Riley, Cournand, and Donald (1951). 